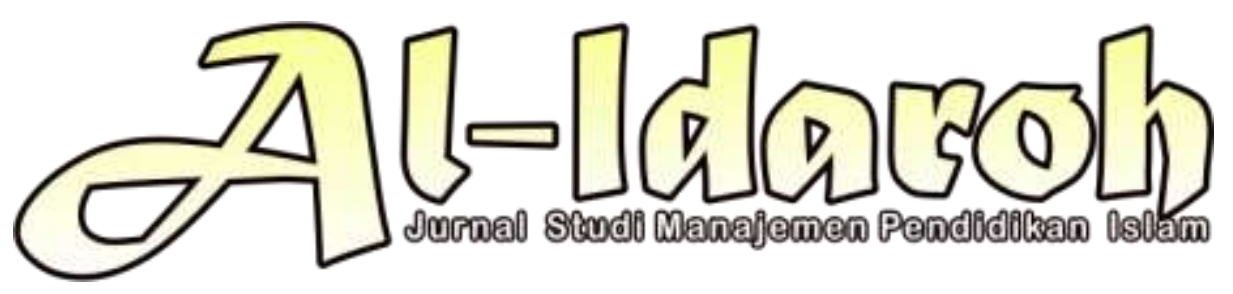

\title{
KEPEMIMPINAN KEPALA MADRASAH DALAM \\ PENINGKATKAN MOTIVASI KERJA GURU DI MA AL-MAHRUSIYAH LIRBOYO KEDIRI
}

\author{
Ali Mustofa \\ STIT Al-Urwatul Wutsqo Jombang \\ Email: aljeP90@yahoo.com \\ Muhammad Abdul Alim \\ STIT Al-Urwatul Wutsqo Jombang \\ Email: alimmuhammadabdul59@gmail.com
}

\begin{abstract}
The head of a madrasa is a person who leads an educational institution where one of the duties is a Motivator. The results showed that: The principal of madrasah increased teacher motivation. Namely a) Motivating morale through providing good infrastructure in accordance with the capabilities of the madrasah and holding general recitation, b) Creating togetherness between teachers and friends. c) Disciplinary fostering, this is done through meetings or deliberations with teachers and employees. d) Giving awards this is done through giving praise and giving gifts or rewards to teachers who are considered to have achievements. e) Creating security in the environment. f) Building active and creative working groups. g) Developing the teaching profession. The inhibiting factor arises from the existence of personal problems in terms of personality such as from the side of his family, the learning that comes in the morning and those that enter the afternoon, must know the ability of each teacher so that when giving assignments according to their abilities, each person's behavior is different so they must also respond in different ways., the morale of the teachers is sometimes great, sometimes it also decreases. The supporting factors are: Always motivating and motivating each other, providing facilities, and understanding the differences in the character of each teacher.
\end{abstract}

Keywords: Principal Leadership, Teacher Work Motivation 


\section{Kepemimpinan Kepala Madrasah dalam Peningkatkan Motivasi Kerja Guru di MA Al-Mahrusiyah Lirboyo Kediri}

\section{Pendahuluan}

Setiap manusia pada hakekatnya adalah pemimpin dan setiap manusia akan dimintai pertanggung jawaban atas kepemimpinannya kelak. Manusia sebagai pemimpin minimal dapat memimpin dirinya sendiri. Setiap organisasi harus ada pemimpinnya yang secara ideal dipatuhi dan disegani bawahannya. Organisasi tanpa pemimpin akan kacau balau. Oleh karena itu harus ada seorang pemimpin yang memerintah dan mengarahkan bawahannya untuk mencapai tujuan individu, kelompok, dan organisasi. ${ }^{1}$

Kepemimpinan merupakan ruh yang menjadi pusat sumber gerak suatu organisasi atau lembaga untuk mencapai tujuan yang telah ditetapkan Hal ini menjadi sebuah alasan diperlukannya seorang yang terampil mengatur, memberi pengaruh, menata, mendamaikan, memberi penyejuk, dan dapat menetapkan arah organisasi, di sinilah diperlukan adanya seorang pemimpin yang mampu melaksanakan tugas kepemimpinannya.

Berbagai perubahan masyarakat, dan krisis multidimensi yang telah lama melanda Indonesia menyebabkan sulitnya menemukan sosok pemimpin ideal yang memiliki komitmen tinggi terhadap tugas dan tanggung jawabnya. Dalam berbagai bidang kehidupan banyak ditemui pemimpin-pemimpin yang sebenarnya kurang layak mengemban amanah kepemimpinannya. Demikian halnya dalam pendidikan, tidak sedikit pemimpin-pemimpin pendidikan karbitan atau amatiran yang tidak memiliki visi dan misi yang jelas tentang lembaga pendidikan atau sekolah yang dipimpinnya ${ }^{2}$. Kondisi yang seperti ini akan mengakibatkan dampak negatif bagi lembaga sekolah terutama di bidang iklim dan budaya sekolah. Pemimpin yang tidak mumpuni akan mengakibatkan organisasi yang dipimpinnya sulit untuk berkembang.

Kepemimpinan seorang kepala sekolah merupakan upaya yang dilakukan dan hasil yang dapat dicapai dalam mengimplementasikan dan mewujudkan tujuan pendidikan secara efektif dan efisien, produktif, dan akuntabel. Oleh karena itu, pemimpin memiliki posisi yang sangat penting dalam menggerakkan lembaganya agar

${ }^{1}$ H. Usman, Manajemen: Teori, Praktek, dan Riset Pendidikan. (Jakarta: Bumi Aksara. 2009), 276.

${ }^{2}$ H. E Mulyasa, Manajemen dan Kepemimpinan Kepala Sekolah. (Jakarta: PT. Bumi Aksara. 2013), 17. 
dapat berjalan sesuai dengan tuntutan masyarakat dan perkembangan kebutuhan zaman, khususnya kemajuan ilmu pengetahuan, teknologi, budaya, dan seni. ${ }^{3}$

Kepala sekolah sebagai seorang pemimpin berperan sebagai figur dan mediator, bagi perkembangan masyarakat dan sekitarnya. Kepala sekolah harus mampu membangun mental, moral, spirit, dan kolektivitas kepada yang dipimpinnya agar tercipta hubungan yang harmonis di lingkungan sekolah. Seorang pemimpin harus mampu memotivasi anggotanya untuk senantiasa melaksanakan tugas dan tanggung jawab sebaik mungkin guna mencapai tujuan organisasi. Dalam memotivasi bawahannya, pemimpin berhadapan dengan dua hal yang mempengaruhi seseorang dalam bekerja, yaitu kemauan dan kemampuan. Kemauan dapat diatasi dengan pemberian motivasi sedangkan kemampuan dapat diatasi dengan mengadakan diklat. Dengan demikian dapat dirumuskan bahwa kinerja manusia yang tampak dipengaruhi oleh fungsi motivasi dan kemampuannya.

Kepala sekolah merupakan faktor kunci dalam penyelenggaraan pendidikan di sekolah. Dia adalah orang yang paling bertanggung jawab untuk memotivasi guruguru dengan memberikan dorongan pengarahan dan motivasi kerja, pembinaan dan pengawasan yang pada akhirnya akan meningkatkan kinerja mereka serta memecahkan masalah yang ada dalam pencapaian tujuan. Kegagalan kepala sekolah menyebabkan lembaga yang dipimpinnya akan terpuruk. Kepemimpinan kepala sekolah sangat menentukan keberhasilan sekolah dalam mewujudkan visi dan misinya sebagai lembaga kependidikan, karena perilaku kepemimpinan yang efektif akan mampu memotivasi guru menciptakan budaya organisasi sekolah yang kondusif untuk mencapai pelaksanaan kerja yang terbaik.

Kepala sekolah yang baik mamapu memotivasi guru dalam menciptakan kepuasan kerja dengan komunikasi yang intensif, memberi insentif, pengelolaan administrasi yang transparan dan memeberikan kemudahan kepada guru dalam melaksanakan pekerjaannya, serta menunjang guru dalam memotivasi aktivitas pembelajaran di sekolah dan memberikan kesempatan kepada guru untuk menyampaikan kritikan dan saran.

${ }^{3}$ H.E Mulyasa, Manajemen dan Kepemimpinan Kepala Sekolah . (Jakarta: PT. Bumi Aksara. 2013), 18 


\section{Kepemimpinan Kepala Madrasah dalam Peningkatkan Motivasi Kerja Guru di MA Al-Mahrusiyah Lirboyo Kediri}

Maslah kepemimpinan dalam islam juga mendapat tempat istimewa untuk mewujudkan khilafah di muka bumi demi terwujudnya kebaikan dan perubahan ke arah yang lebih baik. Demikian juga diutusnya Rasul ke muka bumi untuk memimpin umat menuju keridhaan Allah SWT, sebagaimana di jelaskan dalam Al-Qur'an surat al-baqorah ayat 30 yang berbunyi:

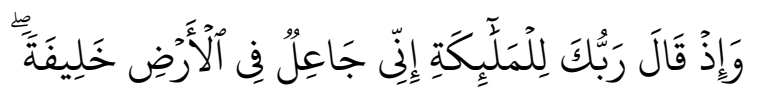

... Ingatlah ketika Tubanmu berfirman kepada Para Malaikat: "Sesunggubnya aku bendak menjadikan seorang khalifah di muka bumi "... ${ }^{4}$

Psikologi kepemimpinan menyatakan bahwa fungsi utama seorang pemimpin adalah mengembangkan sistem motivasi yang efektif, agar para pengikut (bawahannya) mau bekerja sesuai dengan yang di perintahkan pimpinannya. Yang di maksud pengikut atau bawahan dalam hal ini adalah guru dan tenaga kependidikan lainnya. Guru memiliki posisi yang sangat menentukan keberhasilan dalam rancang, mengelola, melaksamakan dan mengevaluasi pembelajaran karena ia memiliki kedudukansebagai figur sentral dalam meningkatkan peroses belajar mengajar. ${ }^{5}$

Motivasi sendiri merupakan faktor psikis yang bersifat non-intelektual. Perannya yang khas adalah dalam hal penumbuhan gairah, merasa senang dan semangat untuk belajar dan mengajar. Siswa dan guru yang memiliki motivasi kuat, akan mempunyai banyak energi untuk melakukan kegiatan belajar mengajar. ${ }^{6}$ Dengan kata lain adanya motivasi yang kuat akan menjadikan seseorang menjadi lebih bersemangat dalam melakukan kegiatan.

Meneliti guru sebagai salah seorang pelaksana pendidikan di sekolah atau sekolah sangat diperlukan. Tidak jarang ditemukan guru yang kurang memiliki gairah dalam melakukan tugasnya, yang berakibat kurang berhasilnya tujuan yang ingin dicapai. Hal itu disebabkan oleh berbagai faktor, salah satunya adalah kurangnya motivasi guru dalam bekerja. Motivasi dapat dipandang sebagai energi dalam diri seseorang yang ditandai oleh munculnya feeling dan didahului dengan tanggapan terhadap adanya tujuan. Pernyataan ini mengandung pengertian tiga pengertian yaitu bahwa motivasi mengawali perubahan energi dalam diri setiap individu, motivasi

\footnotetext{
${ }^{4}$ Al-Baqarah /2: 30

${ }^{5}$ H. Usman, Manajemen: Teori, Praktek, dan Riset Pendidikan. (Jakarta: Bumi Aksara. 2009), 7

${ }^{6}$ S. AM, Interaksi dan Motivasi Belajar Mengajar. (Jakarta: Rajawali. 1968), 75
} 
relevan dengan persoalan kejiwaan, afeksi dan emosi yang dapat menentukan tingkah laku manusia, dan motivasi dirangsang karena adanya tujuan. ${ }^{7}$

Kaitan motivasi dengan kepemimpinan kepala sekolah yang bertugas memberdayakan guru, pemberian motivasi atau dorongan kepada guru agar senantiasa melakukan tugasnya secara disiplin merupakan hal yang wajib dilakukan oleh kepala sekolah. Ketika motivasi kerja guru itu tinggi, guru akan memusatkan seluruh tenaga dan perhatiannya guna mencapai hasil yang maksimal. Kepala sekolah harus benar-benar menjalin komunikasi aktif dan setiap saat mengadakan evaluasi terhadap tugas pengajaran yang telah dilakukan oleh guru. Hal ini dapat tercermin dari pola kepemimpinan yang ditunjukkan oleh kepala sekolah kepada bawahannya. Perilaku pemimpin yang positif dapat mendorong kelompok atau bawahannya untuk senantiasa bekerja sama dalam rangka mewujudkan tujuan sekolah.

Dari penelitian awal yang dilakukan di MA Al-Mahrusyiah Lirboyo Kediri terlihat adanya hubungan yang sinergis antara kepala sekolah dengan para guru dan staf lainnya. Hal tersebut terbukti dengan adanya perhatian yang diberikan kepala madrasah terhadap guru yang dapat membantu memotivasi kerja guru, karena motivasi sangat penting dan harus dimiliki oleh setiap pribadi yang bersangkutan. Kepala madrasah juga tidak segan-segan mengunjungi, menyapa guru dan staf lainnya di ruang kerja mereka. Hubungan yang demikian diharapkan dapat mendorong guru untuk lebih giat melakukan tugasnya. Dalam hal ini, kepala sekolah berperan besar dalam seluruh kegiatan sekolah terutama dalam pembentukan guru yang berkualitas. Model dan gaya kepemimpinannya beserta strategi yang diterapkan akan berpengaruh bagi kinerja guru yang ada di lingkup sekolah.

Meningkatnya motivasi kerja guru akan berimplikasi pada kinerja guru yang akan meningkat pula sehingga pembelajaran di sekolah akan berlangsung secara efektif. Hal demikian akan menambah citra sekolah di masyarakat. Namun hal tersebut tidak akan dapat terjadi tanpa adanya peran seorang kepala sekolah. Sebagai seorang pemimpin, kepala sekolah harus ikut andil dalam membentuk semangat kerja para gurunya agar nantinya kinerja yang mereka berikan dapat optimal.

${ }^{7}$ H. B Uno,. Teori Motivasi dan Pengukuran. (Jakarta: PT Bumi Aksara. 2008).63 


\section{Pembahasan}

1. Kepemimpinan Kepala Madrasah Dalam Meningkatkan Motivasi Kerja Guru di MA Al-Mahrusiyah Lirboyo Kediri

Kepala Madrasah tersusun dari dua kata, yaitu "Kepala" dan "Madrasah". Kepala dapat diartikan orang atau guru yang pemimpin suatu madrasah atau lembaga pendidikan formal. Sedangkan Madrasah ialah bangunan atau lembaga untuk belajar dan mengajar serta tempat menerima dan memberi pelajaran. Adapun menurut pandangan Islam kepala madrasah identik dengan kata ulil amri yang berarti orang pemegang perkara. Maksudnya pemegang perkara yaitu kepala madrasah sebagai seorang pemimpin tertinggi di Madrasah.

Kepemimpinan adalah proses memengaruhi dalam menentukan tujuan organisasi, memotivasi perilaku pengikut untuk mencapai tujuan, memengaruhi untuk memperbaiki kelompok dan budayanya. Selain itu juga memengaruhi interprestasi mengenai peristiwa-peristiwa para pengikutnya, pengorganisasian, dan aktivitas-aktivitas untuk mencapai sasaran, memelihara hubungan kerjasama dan kerja kelompok, perolehan dukungan dan kerjasama dari orang-orang di luar kelompok atau organisasi ${ }^{8}$, Sama halnya dengan kepala madrasah MA AlMahrusiyah Lirboyo Kediri yang selalu menggerakan para guru di madrasah agar terus meningkatkan motivasi kerja sesuai dengan tanggung jawab masing-masing, selalu mengarahkan para guru agar bertugas sesuai dengan tujuan madrasah, memberikan contoh yang baik kepada para guru-guru sehingga mereka dapat mencontoh perilaku kepalamadrasah, serta selalu memberikan motivasi kerja kepada para guru agar selalu meningkatkan semangat melaksanankan tugas dan tanggung jawabnya, juga kepada para guru agar selalu memelihara kebersamaan dan kekeluargaan didalam lingkungan madrasah.

Para guru-guru di MA Al-Mahrusiyah Lirboyo Kediri dituntut untuk mengikuti perintah kepala madrasah, karena kepala madrasah merupakan pemimpin di madrasah. Sebagaimana firman Allah SWT dalam Q.S An-Nisa' (4) ayat 59:

${ }^{8}$ Mulyadi. Kepemimpinan Kepala Sekolah dalam Mengembangkan Budaya Mutu. (Malang: UIN Maliki Press. 2010). 1 


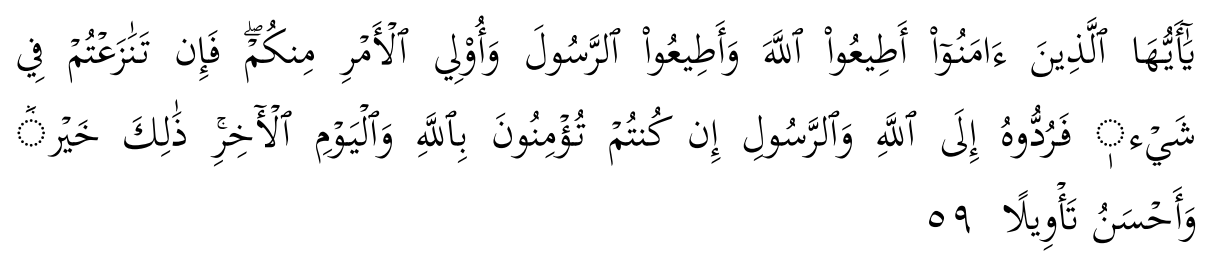

"Hai orang-orang yang beriman, taatilah Allah dan taatilah Rasul (Nya), dan ulil amri di antara kamu. Kemudian jika kamu berlainan pendapat tentang sesuatu, maka kembalikanlab ia kepada Allab (Al Qur'an) dan Rasul (sunnabnya), jika kamu benar-benar beriman kepada Allah dan hari kemudian. Yang demikian itu lebih utama (bagimu) dan lebih baik akibatnya""

Ayat diatas mengandung bahwa seorang pemimpin memiliki kedudukan untuk ditaati selagi perintah tersebut tidak menentang syari'at islam, maka kepala madrasah bisa dikatakan ulil amri atau pemimpin dalam islam. Adapun dalam penelitian ini, peneliti memfokuskan pada kepemimpinan kepala madrasah dalam meningkatkan motivasi kerja guru.

Sebagai motivator, kepala madrasah harus memiliki strategi yang tepat untuk mremberikan motivasi kepada para tenaga kependidikan dalam melakukan berbagai tugas dan fungsinya.

Mulyasa mengungkapkan beberapa prinsip yang dapat diterapakn kepala madrasah untuk mendorong tenaga kependidikan agar mau dan mampu meningkatkan profesionalismenya. Antara lain:

a. Para tenaga kependidikan akan bekerja lebih giat apabila kegiatan yang dilakukan menarik, dan menyenangkan.

b. Tujuan kegiatan perlu disusun dengan jelas dan diinformasikan kepada para tenaga kependidikan dan para tenaga kependidikan dilibatkan dalam penyusunan tujuan tersebut.

c. Para tenaga kependidikan harus selalu diberitahu tentang hasil dari setiap pekerjaannya.

d. Pemberian hadiah lebih baik daripada hukuman,namun sewatu-waktu hukuman juga diperlukan.

e. Usahakan untuk memenuhi kebutuhan tenaga kependidikan dengan jalan memperhatikan kondisi fisiknya, memberikan rasa aman, menunjukan bahwa

${ }^{9}$ Q.S An-Nisa', 4: 59 


\section{Kepemimpinan Kepala Madrasah dalam Peningkatkan Motivasi Kerja Guru di MA Al-Mahrusiyah Lirboyo Kediri}

kepala madrasah memperhatikan mereka, mengatur pengalaman sedemikian rupa sehingga setiap pegawai pernah memperoleh kepuasan dan penghargaan. ${ }^{10}$

Teori diatas sesui dengan fakta yang berada dilapangan bahwa dalam meningkatkan motivasi kerja guru kepala madrasah MA Al-Mahrusiyah Lirboyo Kediri sudah program-program atau kegiatan-kegiatan yang dapat membantu meningkatnya semangat kerja, melalu pemberian hadiah atau rewad yang diberikan kepada guru. Guru diberi kebebasan untuk berinovasi atau memunculkan ide-ide yang baik, dan kepala madrasah selalu memenuhi kebutuhan baik itu berupa fisik maupun non fisik sebisa mungkin tujuannya untuk meningkatkan motivasi mereka dalam berkerja.

Madrasah Aliyah Al-Mahrusiyah Lirboyo Kediri yang sebelumnya bernama MA HM Tribakti merupakan lembaga pendidikan yang berada di bawaah naungan yayasan Al-Mahrusiyah yang didirikan pada tanggal 21 juni 1986 dan diprakarsai oleh alumni UIT dan alumni pondok pesantren lirboyo. kemudian diresmikan oleh KH. Anwar Mansur dengan surat keputusan yayasan pendidikan islam. MA Al-Mahrusiyah Lirboyo Kediri merupakan madrasah yang didalamnya terdapat kegiatan dalam meningkatkan motivasi kerja guru, meningkatkan motivasi kerja guru bukan hal yang mudah, namun tidak menutupi kemungkinan motivasi kerja seseorang dapat berubah seiring berjalannya waktu. Strategi yang digunakan untuk meningkatkan motivasi kerja guru di MA Al-MAhrusiyah Lirboyo Kediri dilakukan melalui program-program yang terdapat dimadrasah. Seperti yang diungkapkan oleh Wahyosumidjo bahwa pelaksanaan meningkatkan motivasi kerja guru dapat melalui ${ }^{11}$ :

a. Memotivasi Semangat Kerja

Menurut Hamzah B. Uno Motivasi semangat kerja guru adalah suatu proses yang dilakukan untuk menggerakkan guru agar perilaku mereka dapat diarahkan pada upaya-upaya yang nyata untuk mencapai tujuan yang telah diucapkan. ${ }^{12}$ Begitupun di MA Al-Mahrusiyah Lirboyo Kediri motivasi semangat kerja ini diaplikasikan melalui pemberian penghargaan, memberikan

${ }^{10}$ H. M. Shulhan, Model Kepemimpinan Kepala madrasah dalam Meningkatkan Kinerja Guru. (Yogyakarta: Teras. 2013). 56-57

${ }^{11}$ Wahyosumidjo. Kepemimpinan Kepala Sekolah. (Jakarta: PT. Raja Grafindo Persada. 2007).

${ }^{12}$ H. B Uno,. Teori Motivasi dan Pengukuran. (Jakarta: PT Bumi Aksara. 2008). 24 
bimbingan atau saran, seperti pembinaan, rapat musyawarah, mengadakan pengajian umum, pelatihan kebiasaan seperti itu yang dilakukan oleh kepala madrasah di MA Al-Mahrusiyah Lirboyo Kediri adalah suatu proses dimana kebutuhan mendorong seseorang untuk melakukan serangkaian kegiatan yang mengarah kepada tercapainya tujuan tertentu dan tujuan organisasi dan untuk memenuhi beberapa kebutuhan. kuat lemahnya motivasi kerja seseorang tenaga kerja ikut menentukan besar kecilnya prestasi.

Pelaksanaannya dilaksanankan melalui pembuatan jadwal kegiatan dilaksanakannya program tersebut, bisa di lingkungan sekolah dan juga di luar lingkungan sekolah. Tujuannya untuk mengembangkan pengetahuan para guru.

b. Menciptakan Kebersamaan

Menciptakan kebersamaan merupakan pendukung meningkatnya motivasi kerja. di MA Al-Mahrusiyah Lirboyo Kediri sangat di butuhkan, hal ini memerlukan kegiatan khusus agar terciptanya kebersamaan di antara guruguru, oleh karena itu kepala madrasah sangat konsisten melakukan kegiatankegiatan yang dapat menciptakan kebersamaan, seperti membantu guru yang sedang mendapatkan musibah, seperti sakit atau yang lainnya seperti ada masalah dalam hal mengajar atau pembuatan bahan ajar maka disitulah kepala madrasah selalu memberikan contoh terhadap guru-guru supaya ikut berkontribusi dalam kebaikan tujuannnya yaitu untuk menciptakan kebersamaan diantara para guru-guru.

c. Pembinaan Disiplin

unsur dari pengertian pembinaan, yaitu pembinaan itu sendiri bisa berupa suatu tindakan, proses, atau pernyataan dari suatu tujan, dan kedua pembinaan itu bisa menunjukan kepada "Perbaikan" atas sesuatu. Disiplin adalah prosedur yang mengkoreksi atau menghukum pegawai karena melanggar peraturan atau prosedur.

penulis dapat menyimpulkan bahwa kepala madrasah MA Al-Mahrusiyah Lirboyo Kediri sudah meneggakan pembinaan disiplin, implementasinya adalah kepala madrasah sering mengadakan rapat pembinaan atau musyawarah tentang masalah-masalah yang ada dilembaga, tujuannya yaitu untuk memahamkan kepada para guru tentang tata tertib dan aturan-aturan yang 


\section{Kepemimpinan Kepala Madrasah dalam Peningkatkan Motivasi Kerja Guru di MA Al-Mahrusiyah Lirboyo Kediri}

berlaku dilingkungan lembaga, selain itu juga ada teguran atau peringatan dari kepala madrasah kepada guru yang kurang disiplin, jika masih melanggar maka kepala mdrasah akan memberikan hukuman sesuai apa yang dilanggarnya dan tidak memberatkan dalam arti hukuman kekeluagaan.

d. Pemberian Penghargaan

penghargaan didefinisikan sebagai ganjaran yang diberikan untuk memotivasi para karyawan agar produktivitasnya tinggi. selain itu reward atau penghargaan adalah imbalan balas jasa yang diberikan oleh lembaga kepada para tenaga kerja, karena tenaga kerja tersebut telah memberikan sumbangan tenaga dan pikiran demi kemajuan lembaga guna mencapai tujuan yang telah ditetapkan. Pemberian penghargaan atau reward yang diterapkan di MA AlMahrusiyah Lirboyo Kediri, dimana para guru di berikan sebuah penghargaan kepada guru yang dianggap memiliki prestasi dalam kerjanya, hal itu dapat menarik perhatian guru-guru yang lain sehingga dengan cara itu dapat seorang guru dapat termotivasi karena adanya dorongan dari kepala madrasah melalui pemberian hadiah tersebut.

Adapun terkait pemberian penghargaan, dalam proses meningkatkan motivasi kerja guru di MA Al-Mahrusiyah Lirboyo Kediri tidak hanya memberikan satu penghargaan saja, namun kepala madrasash juga memberika beberapa penghargaan seperti pemberian pujian, pujian merupakan salah satu bentuk reward yang paling mudah dilakukan, pujian dapat berupa kata-kata, seperti: bagus, baik, bagus sekali, sebagaimana yang dilakukan olleh kepala madrasah, selain pujian berupa kata-kata, pujian yang diberika kepala madrasah dapat juga berupa isyarat atau pertanda misalnya dengan menunjukan ibu jari, dengan tepuk tangan. terdapat empat jenis reward berdasarkan bentuk reward yang diberikan, yaitu: Memberikan Pujian, Pemberian Hadiah, Pemberian penghormatan dan Pemberian Kekuasaan.

e. Menciptakan Keamanan Dilingkunngan Madrasah

lingkungan kerja yang baik meliputi beberapa aspek yang harus diperhatikan misalnya ruangan kerja yang nyaman, kondisi lingkungan yang aman, suhu ruangan yang tetap terdapat percahayaan yang memadai, warna cat ruangan, dan hubungan dengan rekan kerja yang baik. keamanan lingkungan 
kerja yang ada di MA Al-Mahrusiyah Lirboyo Kediri sudah menciptakan keamanan dilingkunagan madrasah dengan diadakanya penjaga keaman, selain itu juga pengaturan ruang kerja yang nyaman, dan lingkungan yang bersih. sehingga guru-guru dapat merasakan ketenangan dalam berkerja dan tidak ada timbul pikiran-pikiran yang hal itu dapat menggangu berkurangnya kualitas kerja sehingga dapat melaksanakan tugasnya maksimal.

f. Membangun Kelompok Kerja Aktif dan Kreatif

Kreativitas adalah kemampuan untuk membuat kombinasi baru, berdasarkan data, informasi, atau unsur-unsur yang ada. Dalam hal ini, mengartikan bahwa kreativitas sesungguhnya tidak perlu menciptakan hal-hal yang baru, tetapi merupakan gabungan (kombinasi) dari hal-hal yang sudah ada sebelumnya ${ }^{13}$. Hal tersebut serupa dengan guru yang ada di MA Al-Mahrusiyah Lirboyo Kediri. Guru memiliki dorongan untuk menjadi publik figur yang kreatif sebab akan mempengaruhi kinerja seorang guru tersebut nantinya. Misalnya dalam menguasai bahan pembelajaran guru senantiasa memotivasi dirinya sendiri supaya mampu menguasai tanpa harus memberikan informasi yang salah kepada siswa dalam penyampaian materi.

Kemudian guru melakukan penilaian hasil belajar siswa hal ini dilakukan untuk mengetahui apakah siswa tersebut sudah mencapai hasil yang telah ditentukan atau belum sehingga sebagai seorang guru dituntut untuk mengetahui tolak ukur siswanya dan memberikan pengarahan yang lebih jika siswa tersebut belum mencapai hasil yang telah ditentukan. Hal itu dilaksanakan didalam rapat kajur yaitu ketua jurusan yang dibuat oleh kepala madrasah, selain itu kepala madrasah juga membetuk MGMP yaitu musyawarah guru mata pelajaran, namun dalam hal itu guru-guru sudah mampu dalam mebuat ide-ide baru sehingga mereka dapat saling memberikan informasi-informasi terkait dengan pembelajaran, selain itu dapat memecahkan permasalahan yang ada sehingga dalam pelaksanaanya kepala madrasah hanya mengarahkan dan menambahkan bila perlu. Sebagaimana yang disampaikan oleh Utami Munandar mengemukakan bahwa kreativitas adalah hasil interaksi

${ }^{13}$ Utamai munandar, mengembangkan bakat dan kreativitas anak sekolah (Jakarta: rineka cipta), 17 


\section{Kepemimpinan Kepala Madrasah dalam Peningkatkan Motivasi Kerja Guru di MA Al-Mahrusiyah Lirboyo Kediri}

antara individu dan lingkungan, kemampuan untuk membuat kombinasi baru, berdasarkan data, informasi, atau unsur-unsur yang sudah ada atau dikenal sebelumnya, yaitu semua pengalaman dan pengetahuan yang telah di peroleh seseorang selama hidupnya baik itu dilingkungan sekolah, keluarga, maupun dari lingkungan masyarakat. ${ }^{14}$

g. Mengembangkan Profesi Guru

Guru merupakan pendidik dan pengajar pada pendidikan anak baik pada jalur sekolah atau pendidikan formal, pendidikan dasar, dan pendidikan menengan. Berkaitan dengan profesi, guru adalah suatu pekerjaan yang membutuhkan pengetahuan, keterampilan, kemampuan, keahlian dan ketelatenan untuk menciptakan anak memilki prilaku yang sesuai harapan. seperti yang di terapkan oleh kepala madrasah di MA Al-MAhrusiyah Lirboyo Kediri bahwa selama ini guru-guru dimadrasah selalu di dukung akan profesinya yang paling utama dilakukan oleh kepala madrasah adalah mengembangkan potensi pedagogiknya yaitu kemampuan mengelola pembelajaran peserta didik yang meliputi pemahaman terhadap peserta didik, perencanaan dan pelaksanaan pembelajaran, evaluasi hasil belajar, dan pengembangan peserta didik untuk mengikutsertakan berbagai potensi yang dimiliki, selain itu dengan di laksanakanya pelatihan-pelatiahan oleh para ahli sehingga hal itu dapat menambah wawasan pengetahuan, keterampilan dan mampu mengembangkan profesinya, selain itu kepala madrasah juga mengirimkan beberapa guru untuk ikut menjadi seorang penulis buku penddikan di tingkat nasional di Jakarta.

Pengembangan profesi guru selama ini di serahkan pada guru itu sendiri. Jika guru itu mau mengembangkan dirinya ssendiri, maka guru itu harus berkualitas, karena itu senantiasa mencari peluang untk meningkatkan kualitas sendiri. Idealnya pemerintah, asosiasi pendidikan dan guru serta satuan pendidikan memfasilitasi guru untuk mengembangkan kemampuan bersifat kognitif berupa pengertian dan pengetahuan utuk hal itu kepala madrasah MA Al-Mahrusiyah LIrboyo Kediri selalu memfasilitasi dan mendukdung, yang

14 Utamai munandar, mengembangkan bakat dan kreativitas anak sekolah (Jakarta: rineka cipta), 17 
demikian itu penting karena dengan cara seperti itu akan meningkatkan kemampuan pedagogic bagi guru. sebagaimana yang di ungkapkan oleh kunandar bahwa:

Profesi adalah suatu pekerjaan atau jabatan yang menuntut keahlian tertentu. Artinya suatu pekerjaan atau jabatan yang disebut profesi tidak dapat dipegang oleh sembarangan orang, tetapi memerlukan persiapan melalui pendidikan dan pelatihan secara khusus. Professional adalah pekerjaan atau kegiatan yang dilakukan oleh seseorang dan menjadi sumber penghasilan kehidupan yang memerlukan keahlian, atau kecakapan yang memenuhi standar mutu atau norma tertentu serta memerlukan pendidikan profesi ${ }^{15}$

Pelaksanaan tidak semudah membuat perencanaan. Kegiatan di atas yang sudah menjadi kegiatan rutin di madrasah, bukan hal yang mudah bagi kepala madrasah untuk mengatur kegiatan tersebut. Mulai dari mengatur guru-guru hingga mengatur peserta didik. Oleh karena itu kepala madrasah memiliki suatu prinsip bahwa bagaimanapun keadaannya kepala madrasah tidak memarahi guru jika ada yang salah ketika melaksanakan tugas, kepala madrasah juga tidak mengekang guru-guru untuk selalu bertindak sesuai perintah kepala madrasah. Namun kepala madrasah memberikan kebebasan kepada para guru untuk bebas berkreatifitas, bebas berekspresi dalam melaksanakan kewajibannya, serta selalu memberi semangat motivasi kepada guru-guru. Jika ada guru yang mengalami kesulitan, kepala madrasah selalu memberi solusi. Bahkan jika ada guru yang mengkritik kepala madrasah pun kepala madrasah menerima krtikian tersebut dengan baik. Hal itu menjadikan kerjasama dan hubungan kepala madrasah serta guru-guru selalu harmonis berjalan dengan baik.

\section{Faktor penghambat dan pendukung dalam meningkatkan motivasi kerja guru di MA Al-Mahrusiyah Lirboyo Kediri}

Faktor penghambat dalam meningkatkan motivasi kerja guru di MA AlMahrusiyah Lirboyo Kediri serta cara penyelesaiannya. Setelah kepala madrasah meningkatkan motivasi kerja guru di MA Al-Mahrusiyah Lirboyo Kediri, terdapat beberapa faktor penghambat pada saat memotivasi kerja guru, di antaranya:

${ }^{15}$ Kunandar.Langkah Mudah Penelitian Tindakan Kelas Sebagai Pengembangan Profesi Guru. (Jakarta. Rajawali Pres. 2012).45 


\section{Kepemimpinan Kepala Madrasah dalam Peningkatkan Motivasi Kerja Guru di MA Al-Mahrusiyah Lirboyo Kediri}

a. Adanya permasalahan personal dari sisi kepribadiannya seperti dari sisi keluarganya.

b. Adanya pembelajaran yang masuk pagi dan yang masuk siang.

c. Harus mengetahui kemampuan setiap guru agar ketika memberi tugas sesuai kemampuannya

d. perilaku setiap orang berbeda sehingga harus menyikapi juga dengan cara tang berbeda.

e. Semangat para guru terkadang besar terkadang juga menurun.

Pelaksanaan meningkatkan motivasi kerja guru tidak selalu lancar sesuai dengan yang diharapkan, adakalanya muncul beberapa kendala atau problem yang dapat mempengaruhi meningkatkan motivasi kerja guru. Motivasi sebagai proses batin atau proses psikologis dalam diri seseorang, sangat dipengaruhi oleh beberapa faktor. Faktor-faktor tersebut antara lain :

a. Faktor Eksternal

Faktor eksternal faktor pendorong yang datang dari luar diri seseorang terutama dari organisasi tempatnya bekerja. Faktor eksternal ini meliputi:

1) Lingkungan kerja

2) Pemimpin dan kepemimpinannya

3) Tuntutan perkembangan organisasi atau tugas

4) Dorongan atau bimbingan atasan

b. Faktor Internal

Faktor internal merupakan faktor daya dorong yang timbul dari dalam diri masing-masing karyawan, berupa:

1) Pembawaan individu

2) Tingkat pendidikan

3) Pengalaman masa lampau

4) Keinginan atau harapan masa depan.

Setiap hambatan pasti ada cara penyelesaiannya, berikut adalah faktor pendukung dan upaya yang dilakukan oleh kepala madrasah sesuai dengan hasil wawancara dengan observasi yang dilakukan peneliti: 
a. Selalu memotivasi dan saling memotivasi, baik diluar rapat maupun didalam rapat, sehingga kepala madrasah mampu menjadikan orang-orang disekelilingnya atau guru-guru itu semangat dalam kerjanya.

b. Memberikan fasilitas sesui dengan kemampuan kepal madrasah.

c. Kepala madrasah mampu memahamai perbedaan watak setiap guru.

d. Semua Guru rata-rata tidak mengajar kemana-mana.

e. Kepala madrasah bersikap netral, tidak mengekang para bawahannya, sehingga guru-guru lebih beleluasa untuk berkreatifitas.

f. Yayasan yang sangat terbuka sekali, artinya memahami proses pendidikan dengan kata lain selalu mendukung akan berjalannya suatu kegiatan dengan cara memberikan fasilitas yang mencukupi.

Menurut Kort dalam mengatakan motivasi merupakan hasil faktor internal dan eksternal. Motivasi adalah upaya untuk menimbulkan rangsangan, dorongan ataupun pembangkit tenaga seseorang agar mau berbuat sesuatu atau memperlihatkan perilaku tertentu yang telah direncanakan untuk mencapai tujuan yang telah ditetapkan ${ }^{16}$.

a. Memberikan apa yang dibutuhkan guru-guru untuk menunjang kegiatan apapun selagi baik.

b. mengadakan pendekatan dengan para guru.

Untuk meningkatkan motivasi kerja guru dapat di tempuh dengan beberapa prinsip dalam memotivasi kerja guru, yaitu:

a. Prinsip Partisipasi

Agar dapat meningkatkan motivasi kerja pegawai, pegawai perlu diberikan kesempatan dalam berpartisipasi menentukan tujuan yang akan dicapai oleh pemimpinnya.

b. Prinsip komunikasi

Komunikasi yang baik antara pemimpin dan pegawai dapat memunculkan efek positif bagi budaya organisasi.

16 Zafri, Berfikir Kritis pembelajaran sejarah, jurnal Dakronika FIS UNP. 2012:3-4 


\section{Kepemimpinan Kepala Madrasah dalam Peningkatkan Motivasi Kerja Guru di MA Al-Mahrusiyah Lirboyo Kediri}

c. Prinsip mengakui andil bawahan

Dengan adanya pengakuan akan keikutsertaan pegawai dalam usaha pencapaian tujuan organisasi akan meningkatkan motivasi kerja pegawai tersebut.

d. Prinsip pendelegasian wewenang

Pemimpin yang mampu memberikan wewenang kepada bawahannya untuk sewaktu-waktu dapat mengambil keputusan terhadap pekerjaan yang dilakukan akan dapat membuat pegawai yang bersangkutan termotivasi.

e. Prinsip memberi arahan

Pemimpin memberikan perhatian dan arahan yang jelas kepada bawahannya akan dapat memotivasi pegawai tersebut.

Teori diatas seperti pelaksanaan meningkatkan motivasi kerja guru yang berlaku di MA Al-Mahrusiyah Lirboyo Kediri, Dengan adanya pemberian motivasi dari kepala sekolah terhadap guru diharapkan nantinya guru akan memiliki semangat yang tinggi dalam menyelesaikan tugas dan tanggung jawabnya sehingga kinerja guru menjadi meningkat. Pemberian motivasi sendiri tidak selamanya harus berupa pemenuhan kebutuhan dalam hal materi saja melainkan melalui hubungan dan komunikasi yang baik pun akan dapat meningkatkan motivasi kerja mereka.

\section{Kesimpulan}

Kepala madrasah meningkatkan memotivasi kerja guru. yaitu a) Memotivasi semangat kerja melalui memberikan sarana prasarana yang baik sesuai dengan kemampuan madrasah dan mengadakan pengaiian umum, b) Menciptakan kebersamaan diantara para guru dan kariyawan,. c) pembinaan disiplin, hal ini dilakukan melalui kegiatan rapat atau musyawarah bersama para guru dan karyawan. d) Memberikan penghargaan hal ini dilakukan melalui pemberian pujian dan memberikan hadiah atau reward kepada guru yang dianggap memiliki prestasi. e) Menciptakan keamanan dilingkungan. f) membangun kelompok kerja aktif dan kreatif. g) mengembangkan profesi guru. Faktor penghambatnya yaitu timbul dari Adanya permasalahan personal dari sisi kepribadiannya seperti dari sisi keluarganya, Adanya pembelajaran yang masuk pagi dan yang masuk siang, harus mengetahui 
kemampuan setiap guru agar ketika memberi tugas sesuai kemampuannya, perilaku setiap orang berbeda sehingga harus menyikapi juga dengan cara tang berbeda, semangat para guru terkadang besar terkadang juga menurun. Adapun faktor pendukung yaitu: Selalu memotivasi dan saling memotivasi, memberikan fasilitas, dan memahamai perbedaan watak setiap guru.

\section{Daftar Rujukan}

Usman, H. Manajemen: Teori, Praktek, dan Riset Pendidikan. Jakarta: Bumi Aksara, 2009

Mulyasa, H. E. Manajemen dan Kepemimpinan Kepala Sekolah. Jakarta: Bumi Aksara, 2013

AM, S. Interaksi dan Motivasi Belajar Mengajar. Jakarta: Rajawali, 1968.

H. B Uno. Teori Motivasi dan Pengukuran. Jakarta: PT Bumi Aksara, 2008.

Mulyadi. Kepemimpinan Kepala Sekolah dalam Mengembangkan Budaya Mutu. Malang: UIN Maliki Press, 2010.

M. Shulhan H. Model Kepemimpinan Kepala madrasah dalam Meningkatkan Kinerja Guru. Yogyakarta: Teras, 2013

Wahyosumidjo. Kepemimpinan Kepala Sekolah. Jakarta: Raja Grafindo Persada, 2007.

Munandar, Utamai, Mengembangkan bakat dan kreativitas anak sekolah, Jakarta: rineka cipta, 2017.

Kunandar. Langkah Mudah Penelitian Tindakan Kelas Sebagai Pengembangan Profesi Guru. Jakarta. Rajawali Pres, 2012.

Zafri. Berfikir Kritis pembelajaran sejarah, jurnal Dakronika FIS UNP, 2012. 